\title{
PENGENDALIAN MUTU STATISTIK PRODUK AKHIR PAPERBOARD (STUDI KASUS PT SURYA PAMENANG KEDIRI JAWA TIMUR)
}

\author{
STATISTICAL QUALITY CONTROL OF PAPERBOARD \\ (CASE STUDY OF PT SURYA PAMENANG KEDIRI JAWA TIMUR)
}

\author{
Azimmatul Ihwah*) dan Burhan Rafid Ekatama \\ Jurusan Teknologi Industri Pertanian, Fakultas Teknologi Pertanian, Universitas Brawijaya \\ J1. Veteran Malang 65145, Malang, Jawa Timur \\ *Email: azimmatul.ihwah@gmail.com
}

Makalah: Diterima 20 Agustus 2018; Diperbaiki 25 Januari 2019; Disetujui 15 Februari 2019

\begin{abstract}
Product quality control is an effort to minimize defective products from products produced by the company. Without the control of product quality, it will cause a large loss for the company, because irregularities are not known so that repairs cannot be carried out and eventually irregularities will be sustained. Paper are the most common products around us. One of the paper manufacturing industries in Indonesia is PT. Surya Pamenang. The purpose of this study was to determine whether the final product of paperboard was controlled statistically in quality. Quality control statistics were carried out using Pareto Diagram, $\bar{x}-R$ Control Chart and Fishbone Diagram. Data were taken in December 2017 and January 2018. Samples were carried out every one reel from each cardboard to the end of the Board Making unit. Then, the smoothness test from Back Side (BS) and Printing Side (PS) was conducted. From the Pareto diagram obtained $80 \%$ of the most types of disability, namely the Smoothness level of the high PS paper surface with a value of 10, the surface color of the bluish PS paper with a value of 8 and bowl with a value of 7. The control map results showed that the smoothness quality parameter at PS was still really need attention from the company, because in successive months these parameters indicate that the quality was not statistically controlled. The results of the analysis of causes of disability on paperboard were personnel, machines, material, and environment.
\end{abstract}

Keywords: control chart, fishbone diagram, paperboard, pareto diagram, statistical quality control

\section{ABSTRAK}

Pengendalian kualitas produk merupakan usaha untuk meminimalisasi produk cacat dari produk yang dihasilkan perusahaan. Tanpa adanya pengendalian kualitas produk akan menimbulkan kerugian yang besar bagi perusahaan, karena penyimpangan-penyimpangan tidak diketahui sehingga perbaikan tidak bisa dilakukan dan akhirnya penyimpangan akan berkelanjutan. Produk kertas adalah produk yang paling umum dijumpai disekitar kita. Salah satu industri manufaktur kertas di Indonesia adalah PT. Surya Pamenang. Tujuan penelitian ini adalah untuk mengetahui apakah produk akhir kertas karton sudah terkendali mutunya secara statistik. Pengendalian kualitas statistik dilakukan dengan menggunakan diagram Pareto, Peta Kendali $\bar{x}-R$ dan diagram Fishbone. Data diambil pada bulan Desember 2017 dan bulan Januari 2018. Pengambilan sampel uji dilakukan pada setiap satu reel dari tiap kertas karton jadi di akhir unit Board Making. Kertas yang diteliti adalah kertas jenis ICB 230. Dari sampel uji ini dilakukan uji smoothness dari Back Side (BS) dan Printing Side (PS). Dari diagram Pareto diperoleh $80 \%$ jenis kecacatan terbanyak yaitu tingkat Smoothness dari permukaan PS kertas tinggi dengan nilai 10, warna permukaan PS kertas kebiruan dengan nilai 8 dan mangkak (kekuningan) dengan nilai 7. Hasil peta kendali menunjukkan bahwa parameter mutu smoothness pada PS ini masih sangat perlu perhatian dari perusahaan, karena dalam bulan berturut-turut parameter tersebut menunjukkan bahwa kualitasnya belum terkendali secara statistik. Hasil analisis penyebab kecacatan pada kertas karton yaitu personnel, machines, material, dan environment.

Kata kunci: peta kendali, diagram sebab akibat, kertas karton, diagram pareto, pengendalian kualitas statistik

\section{PENDAHULUAN}

Produk kertas adalah produk yang paling umum dijumpai. Mulai dari buku tulis, buku pelajaran, hingga selampai juga merupakan produk kertas yang sering dijumpai. Menurut Kementrian Perindustrian (2018), kinerja ekspor industri kertas di Indonesia berhasil menduduki peringkat pertama, dan industri pulp peringkat ketiga untuk ekspor produk kehutanan selama tahun 2011-2017. Pada 2017, kedua industri itu menyumbang ke devisa negara USD 5,8 miliar, berasal dari kegiatan ekspor pulp sebesar USD 2,2 miliar ke beberapa negara tujuan utama yaitu China, Korea, India, Bangladesh dan Jepang serta ekspor kertas sebesar USD 5,6 miliar ke negara Jepang, Amerika Serikat, Malaysia, Vietnam dan China. Salah satu industri manufaktur 
kertas di Indonesia adalah PT. Surya Pamenang. Industri ini telah memproduksi kertas karton sebanyak 150.000 ton per tahun. Juga telah melakukan ekspor ke lebih dari 20 negara di dunia, seperti Cina, Thailand, Jerman, Australia, dan negara lainnya.

Dari sekian banyak produk kertas yang sering dijumpai, tentunya tidak asing dengan salah satu jenis kertas yaitu kertas karton (paperboard). Jenis kertas karton sering dijumpai pada kemasan distribusi (kardus, karton tebal) ataupun sering dijumpai pada kemasan pak produk tertentu (rokok, produk rumah tangga kebanyakan). Jenis kertas ini adalah jenis kertas yang memiliki banyak kelebihan, misalnya mudah didaur ulang, bahannya cukup kuat dan ringan sesuai penggunaannya, serta mudah untuk menyesuaikan produk yang nantinya menggunakan kertats karton sebagai kemasannya.

Salah satu bentuk perhatian terhadap kualitas pulp dan kertas adalah dengan memiliki sertifikasi ISO 9001:2008 seperti yang telah didapatkan oleh PT. Surya Pamenang. ISO 9001:2008 adalah standar internasional untuk sistem manajemen kualitas terhadap barang dan jasa. Wujud sistem manajemen kualitas yang umum digunakan adalah pengendalian mutu statistik terhadap produk akhir. Dengan adanya manajemen kualitas yang baik, maka produk yang diproduksi akan tetap terjaga dalam spesifikasinya atau konstannya nilai pengukuran terhadap produk.

Pengendalian kualitas secara statistik (Statistical Quality Control (SQC)) adalah metode pengendalian terhadap mutu dari subyek dengan menggunakan dasar-dasar statistik dalam metodenya. SQC juga digunakan untuk mengumpulkan dan menganalisis data hasil pemeriksaan terhadap sampel dalam kegiatan pengawasan kualitas produk (Arifianti, 2013). Selain itu SPC juga digunakan untuk mengukur kualitas sekarang dari produk atau jasa dan mendeteksi apakah proses barang atau jasa mengalami perubahan yang akan mempengaruhi kualitas (Heizer dan Render, 2005 dikutip oleh Kartika, 2013). Beberapa teknik yang umum digunakan dalam pengendalian kualitas secara statistik diantaranya: diagram pareto, peta kendali, dan diagram sebab akibat (Nur dan Suyuti, 2017). Terdapat 2 jenis peta kendali, yaitu peta kendali variabel dan peta kendali atribut. Peta kendali variabel digunakan jika karakteristik kualitas yang akan dikendalikan diperoleh melalui pengukuran dan dinyatakan dalam skala kontinu. Macam peta kendali variabel ada dua, yaitu peta $\bar{X}-R$ dan peta $\bar{X}-s$. Sementara itu, peta kendali atribut digunakan jika karakteristik kualitas yang akan dikendalikan tidak diperoleh melalui pengukuran, misalnya pemeriksaan karakteristik produk yang digolongkan ke dalam produk yang sesuai atau tidak sesuai (Montgomery, 2005).
Pada hasil penelitian yang dilakukan oleh Primastuti (2014) mengenai pengontrolan kualitas produk menggunakan metode diagram kontrol multivariat np (Mnp) dalam Usaha peningkatan Kualitas pada PT Coca-Cola Amatil Indonesia, Semarang diperoleh bahwa proses produksi pada fase II belum terkendali karena terdapat 10 data pengamatan yang out of control, meskipun pada fase I telah terkendali setelah dilakukan penanganan, namun secara keseluruhan proses produksi belum stabil.Kemudian dilanjutkan untuk memeriksa penyebab kecacatan menggunakan diagram Fishbone.

Pada penelitian ini digunakan peta kendali $\bar{X}-R$ karena peta kendali yang dibuat berdasarkan variabel mutu yang diukur pada produk kertas karton.Selain itu, tujuan penelitian ini adalah untuk mengetahui seberapa besar simpangan (range) proses yang terjadi dalam proses produksi paperboard.

\section{METODE PENELITIAN}

Metode penelitian yang digunakan dalam penelitian ini adalah metode kuantitatif. Data yang diambil berupa yang digunakan adalah parameter smoothness dari Back Side (BS) dan Printing Side (PS) kertas karton. Selanjutanya alat yang digunakan untuk memeriksa apakah sampel telah terkendali mutunya secara statistik yaitu diagram pareto, peta kendali $\bar{X}-R$, dan diagram fishbone.

Penyebab kecacatan produk kertas karton akan menggunakan alat bantu statistik Diagram Pareto, Peta Kendali $\bar{X}-R$ dan Diagram Sebab Akibat. Diagram Pareto digunakan untuk mendeteksi penyebab kecacatan terbesar dengan melihat proporsinya. Selanjutnya peta kendali akan dibuat berdasarkan penyebab terbesar hasil kesimpulan dari Diagram Pareto dengan melihat variabel kuantitatif mana yang mempengaruhi kecacatan produk. Terakhir dalam Diagram Fishbone akan dicari penyebab kecacatan sekaligus pemberian solusi terbaik untuk mengatasi penyebab kecacatan produk.

Dalam melakukan pengukuran parameter pada produk kertas karton, jenis kecacatan dicacat satu-persatu dengan melihat dokumentasi perusahaan yang berisi laporan kecacatan produk yang ditentukan oleh pihak Laboratorium FPC, yang nantinya akan dilaporkan ke Unit Board Making. Untuk data primer, peneliti melakukan studi observasi secara langsung ke dalam proses akhir produk kertas karton beserta pengujian pada produk akhir yang dilakukan perusahaan.

Pengambilan sampel uji dilakukan pada setiap satu reel dari tiap kertas karton jadi di akhir unit Board Making. Untuk jenis kertas yang diteliti yaitu dengan jenis ICB 230. Ukuran pengambilannya adalah dengan lebar kurang lebih 1 meter, dan panjangnya adalah 4,2 meter (panjang reel). Dari sampel uji ini nantinya akan dilakukan uji 
gramatur, caliper, smoothness, roughness, glossy, internal bound, moisture, tensile strength, bending stiffness, brightness, uji visual, uji Cobb 60". Parameter dan standar mutu kertas karton dapat dilihat pada Tabel 1.

Tabel 1. Parameter dan standar mutu kertas karton PT. Surya Pamenang

\begin{tabular}{|c|c|c|}
\hline Parameter & Definisi & $\begin{array}{c}\text { Standar } \\
\text { mutu }\end{array}$ \\
\hline Gramatur & $\begin{array}{l}\text { Tingkat berat } \\
\text { kertas per luas } \\
\text { permukaan } \\
\text { tertentu }\end{array}$ & $\begin{array}{l}220,8-239,2 \\
\mathrm{~g} / \mathrm{cm}^{2}\end{array}$ \\
\hline Thickness & $\begin{array}{l}\text { Ketebalan } \\
\text { sampel kertas } \\
\text { dengan rentang } \\
\text { nilai tertentu }\end{array}$ & $\begin{array}{l}302,4-327,6 \\
\text { mikron }\end{array}$ \\
\hline Smoothness & $\begin{array}{l}\text { Kehalusan dari } \\
\text { masing-masing } \\
\text { permukaan } \\
\text { kertas }\end{array}$ & $\leq 30$ \\
\hline Roughness & $\begin{array}{l}\text { Tingkat } \\
\text { kekasaran dari } \\
\text { permukaan } \\
\text { kertas karton }\end{array}$ & $<1,1$ mikron \\
\hline Glossy & $\begin{array}{l}\text { Tingkat } \\
\text { kekilapan dari } \\
\text { permukaan } \\
\text { kertas }\end{array}$ & $45 \%-60 \%$ \\
\hline $\begin{array}{l}\text { Internal } \\
\text { Bound }\end{array}$ & $\begin{array}{l}\text { Kekuatan dari } \\
\text { ikatan kertas } \\
\text { pada masing- } \\
\text { masing lapisan } \\
\text { kertas karton }\end{array}$ & $\geq 100$ \\
\hline Moisture & $\begin{array}{l}\text { Kelembaban } \\
\text { kertas karton } \\
\text { yang diuji tepat } \\
\text { setelah } \\
\text { diproduksi }\end{array}$ & $5 \%-8 \%$ \\
\hline $\begin{array}{l}\text { Bending } \\
\text { stiffness }\end{array}$ & $\begin{array}{l}\text { Kekuatan tekuk } \\
\text { dari kertas }\end{array}$ & $-1,9-(-0,9)$ \\
\hline Brightness & $\begin{array}{l}\text { Tingkat warna } \\
\text { dari permukaan } \\
\text { kertas }\end{array}$ & $144-176$ \\
\hline Visual & $\begin{array}{l}\text { Penampakan } \\
\text { permukaan } \\
\text { kertas }\end{array}$ & $\begin{array}{l}\text { Tidak } \\
\text { terdapat } \\
\text { cacat } \\
\text { coating, } \\
\text { kotor, } \\
\text { bersisik, pola } \\
\text { panu, formasi } \\
\text { kurang baik, } \\
\text { streak, } \\
\text { bercak } \\
\text { coating, } \\
\text { cacat gloss }\end{array}$ \\
\hline Cobb 60" & $\begin{array}{lr}\text { daya } & \text { serap dari } \\
\text { suatu } & \text { sampel } \\
\text { kertas } & \end{array}$ & $\geq 100$ \\
\hline
\end{tabular}

Sumber: PT Surya Pamenang (2017)
Sampel uji selanjutnya dibawa ke laboratorium kertas jadi (FPC, Finishing Product Control). Sampel kertas karton yang akan diuji didalam laboratorium FPC mengikuti standar yang ada didalam TAPPI (Technical Association of Pulp and Pulper Industry) Seri 891/1 dan ISO 2469-2470. Untuk standar dari lingkungan laboratorium adalah diantaranya suhu dengan nilai $23^{\circ} \mathrm{C} \pm 1^{\circ} \mathrm{C}$, dan kelembaban relatif dengan nilai $50 \% \pm 2 \%$.

Hasil pengukuran setiap parameter uji pada sampel dimasukkan kedalam sistem program yang dimiliki perusahaan untuk dapat langsung diketahui apakah hasil pengujian sesusai dengan standar atau tidak. Didalam sistem program, nilai akhir dari masing-masing pengukuran parameter akan dihitung rata-rata dan disesuaikan dengan batas standar yang dimasukkan kedalam program. Hasil yang ada didalam program akan ditampilkan tidak hanya di Unit bagian FPC, melainkan juga di unit lain yang berhubungan langsung dengan tiap-tiap parameter pengukuran.

Data primer diambil mulai dari tanggal 8 Januari 2018 hingga 7 Februari 2018. Teknik pengambilan sampel menggunakan simple random sampling. Caranya yaitu menentukan secara random pada jam berapa dalam setiap harinya sampel produk kertas karton diambil. Sementara itu, data bulan Desember 2017 merupakan data sekunder yang diperoleh dari data yang ada pada perusahaan.

\section{HASIL DAN PEMBAHASAN}

\section{Diagram Pareto}

Jenis kecacatan yang dilaporkan didalam diagram pareto ini adalah kecacatan produk kertas selama produksi dengan tidak melihat jenis kertas apa yang diproduksi. Dari diagram pareto dapat dilihat jenis kecacatan terbanyak yaitu: (1) tingkat Smoothness dari permukaan PS kertas tinggi dengan kuantitas 10, (2) warna permukaan PS kertas kebiruan dengan kuantitas 8, (3) warna permukaan PS kertas mangkak (kekuningan) dengan kuantitas 7, (4) nilai thickness kertas turun sebanyak 3, (5) terjadi cacat coating dengan kuantitas 1, dan (6) kertas mengalami curling maupun cacat dengan sebab lain sebanyak 1. Diagram pareto dapat dilihat pada Gambar 1.

Penelitian yang dilakukan oleh Devani dan Wahyuni (2016), dalam produksi kertas terdapat 4 jenis kecacatan, yaitu wavy, rewinder wrinkle, dented roll, dan less diameter. Dari keempat jenis kecacatan tersebut, didominasi oleh kecacatan wavy sebesar $81,7 \%$. Oleh karena itu, perbaikan diprioritaskan pada jenis kecacatan wavy. Diharapkan dengan perbaikan tersebut, jumlah kecacatan sebesar 18,3\% dapat ikut membaik dengan sendirinya. Hal ini sesuai pula dengan prinsip Pareto (Pareto's Law), bahwa $20 \%$ dari cacat sistem menyebabkan $80 \%$ masalah. 


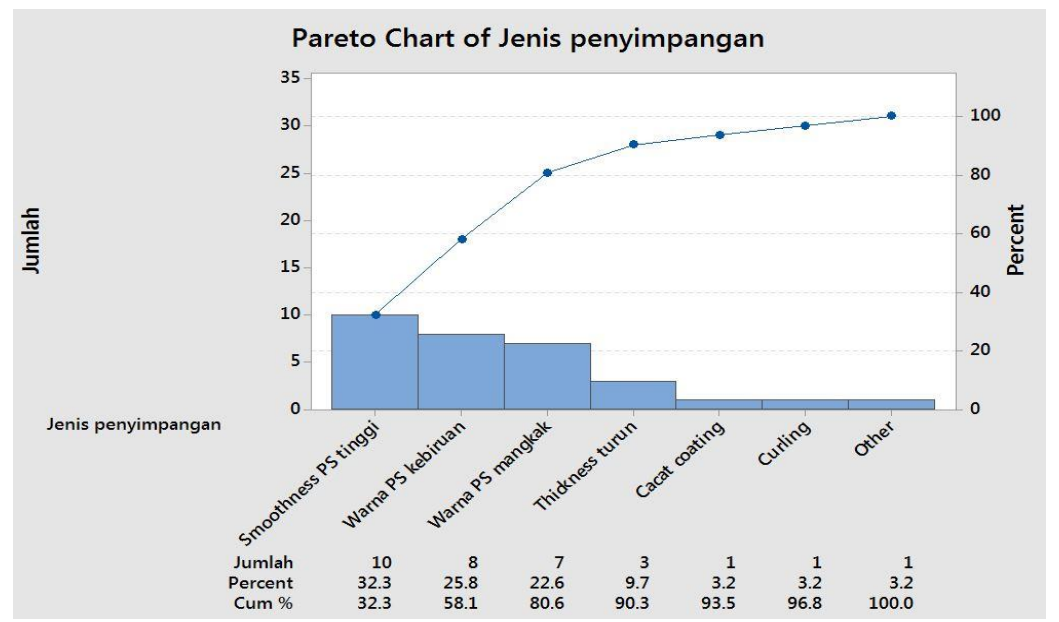

Gambar 1. Diagram pareto jenis penyimpangan kertas karton pada tanggal 8 Januari 2018 hingga 7 Februari 2018

Jadi berdasarkan prinsip tersebut, maka perusahaan harus menyelesaikan $80 \%$ permasalahan pada nilai Smoothness PS tinggi, warna PS kebiruan, dan permasalahan warna PS mangkak. Peta kendali variabel berupa peta $\bar{X}-R$, data yang diinputkan harus berupa data kauntitatif. Jadi parameter Smoothness PS, menjadi pembahasan didalam alat kendali kualitas bagan kendali proses, sementara itu untuk keseluruhan $80 \%$ masalah kecacatan yaitu Smoothness PS tinggi, warna PS Kebiruan dan warna PS mangkak menjadi poin pembahasan dalam alat kendali kualitas diagram sebab akibat.

\section{Peta Kendali $\bar{X}$ dan $\mathbf{R}$ Smoothness sisi PS (Printing Side)}

Data untuk bulan Desember 2017 dan Januari 2018 untuk Printing Side berupa data sekunder yang diambil berdasarkan rekapitulasi data oleh perusahaan. Data diambil dengan sebanyak 30 observasi, dan tiap observasinya diambil 4 data pengujian. Peta $\bar{X}-\mathrm{R}$ untuk Printing Side dapat dilihat pada Gambar 2 dan 3.

Berdasarkan grafik Peta $\bar{X}$ pada Gambar 2, dapat dilihat terdapat 2 poin observasi yang keluar dari batas UCL. Poin tersebut adalah poin ke-3 dan ke-19. Nilai ini menjadi bahan evaluasi oleh perusahaan terhadap observasi ke-3 dan ke-19. Saran yang dapat diberikan kepada perusahaan yaitu perlu dilakukan pengecekan ulang terhadap seluruh pengaturan di bagian Coating Section. Serta kebersihan dari Blade Coater yang dapat mengganggu nilai Smoothness. Hal ini disebabkan karena coating section sebagai tempat aplikasi bahan coating ke bagian permukaan kertas sehingga merupakan proses terpenting dalam menentukan smoothness kertas.

Pada Gambar 3, pada Peta $\bar{X}$ dapat dilihat terdapat 6 poin observasi yang keluar dari batas LCL, dan 3 poin observasi yang keluar dari batas UCL. Poin yang keluar dari batas LCL adalah poin pertama, ke-2 dan ke-10. Poin yang keluar dari batas UCL adalah poin ke-18, ke-22, dan ke-24.Nilai ini menjadi bahan evaluasi oleh perusahaan terhadap observasi poin pertama, kedua, ke-10, ke-18, ke-22 dan ke-24. sedangkan berdasarkan grafik pada Peta $\mathrm{R}$ untuk Gambar 5, dapat dilihat bahwa terdapat satu poin observasi data yang tidak masuk kedalam batas yang telah ditentukan. Poin observasi tersebut berada pada poin ke-25 dengan nilai 10. Maka dari itu karena terdapat satu data yang berada diluar batas, maka dilakukan perhitungan kembali dengan menghilangkan poin observasi ke-25. Hal ini juga dilakukan pada peta $\bar{X}$.

Jika terdapat nilai yang keluar dari batas bawah dan atas pada peta kendali, maka lakukan identifikasi dan hilangkan nilai tersebut. Setelah itu gambar ulang Peta $\bar{X}-\mathrm{R}$ berdasarkan data dan batas yang baru, lalu amati kembali (Badiru et al., 2012). Terdapat poin observasi yang keluar dari batas dapat disebabkan karena adanya jumlah bahan coating yang diberikan kepada kertas tidak sesuai dengan ketentuan (terlalu banyak atau terlalu sedikit), atau bisa juga dikarenakan adanya pengaturan di dalam mesin produksi yang tidak sesuai (terutama di Coater Section). Sementara itu dalam penelitian lain mengenai analisis peta kendali $p$ menjelaskan bahwa perbandingan hasil antara peta kendali $p$ konvensional, peta kendali $p$ yang di standarisasi, dan yang distandarisasi untuk proses pendek yang dapat terlihat perbedaannya dari batas - batas kendali dan hasil data out of control tiap peta kendali tersebut. Untuk peta kendali $p$ konvensional dan peta kendali $p$ yang distandarisasi dengan batas kendali yang berbeda terdapat kesamaan hasil adanya 3 data out of control.

Namun, pada peta kendali p yang distandarisasi untuk proses pendek, walaupun batas kendali sama dengan peta kendali $p$ yang distandarisasi terdapat perbedaan hasil yaitu hanya adanya 1 data out of control, sedangkan untuk peta 
kendali $p$ konvensional dan peta kendali $p$ yang distandarisasi untuk proses pendek sangat berbeda dari segi batas kendali dan hasil data out of control

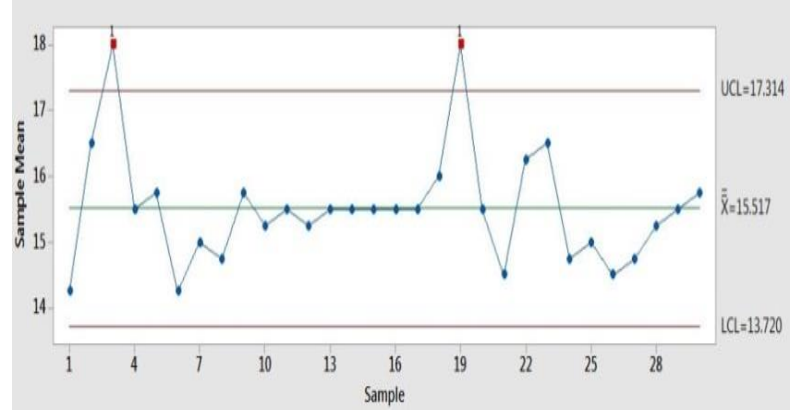

(a)
(Arsyad, 2017). Gambar dari Peta $\bar{X}-\mathrm{R}$ perbaikan dapat dilihat pada Gambar 4 dan Gambar 5.

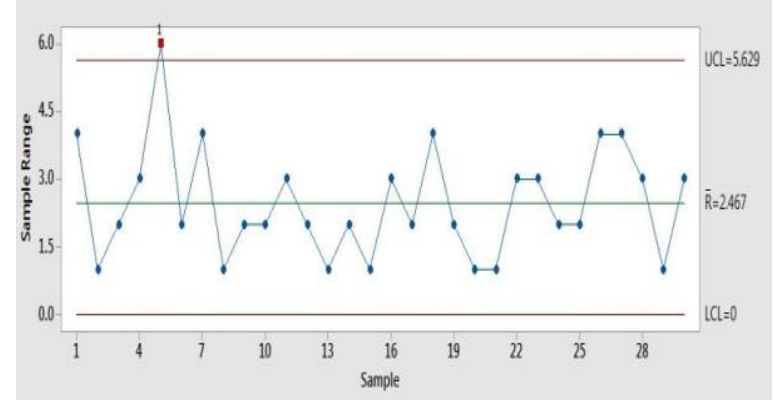

(b)

Gambar 2. (a) Peta $\bar{X}$ parameter smoothness PS bulan Desember 2017, (b) Peta $R$ parameter smoothness PS bulan Desember 2017

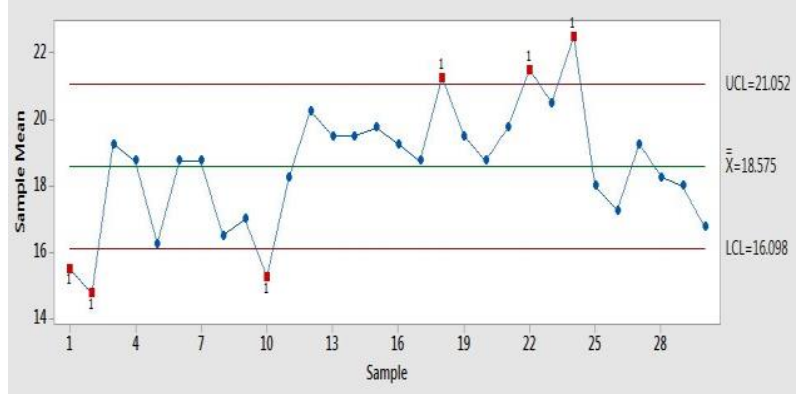

(a)

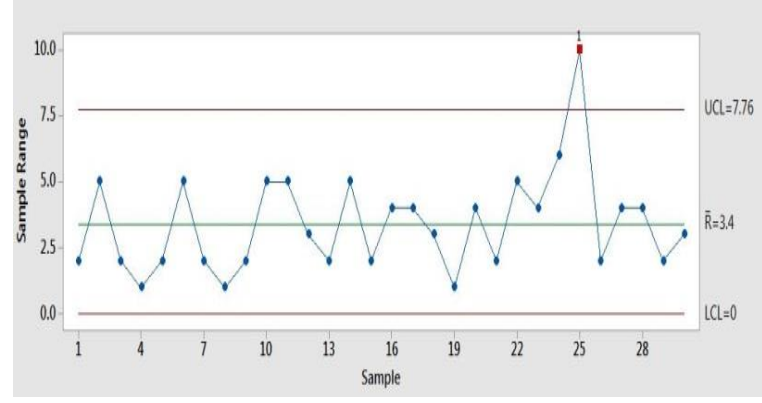

(b)

Gambar 3. (a) Peta $\bar{X}$ parameter smoothness PS bulan Januari 2018, (b) Peta $R$ parameter smoothness PS bulan Januari 2018

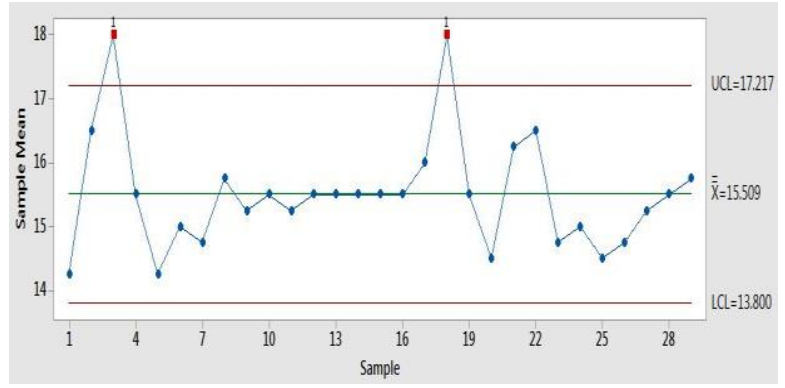

(a)

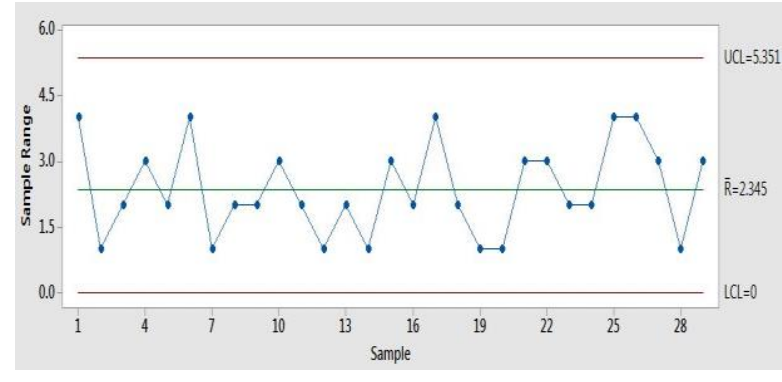

(b)

Gambar 4.(a) Peta $\bar{X}$ perbaikan barameter smoothness PS bulan Desember 2017, (b) Peta $R$ perbaikan parameter smoothness PS Desember 2017

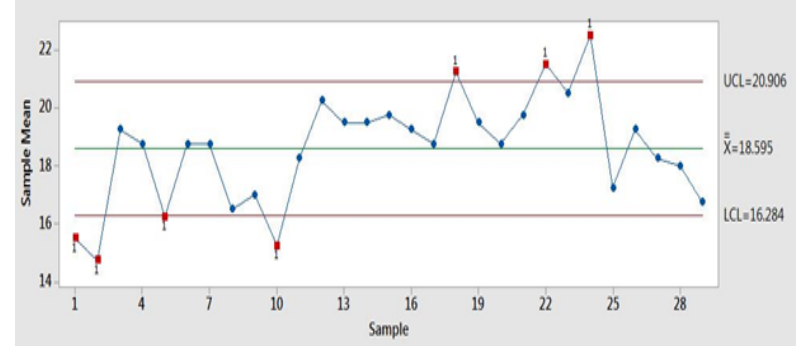

(a)

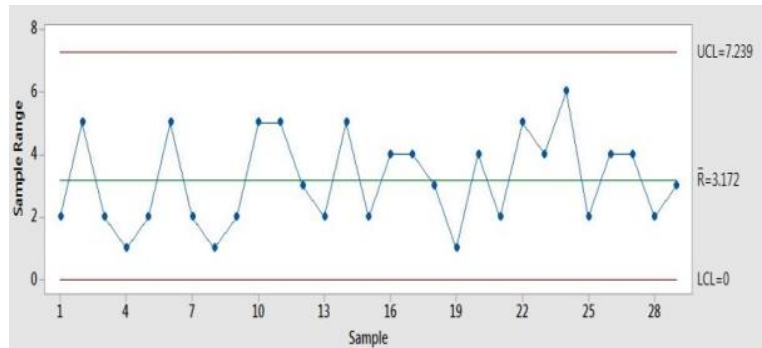

(b)

Gambar 5. (a) Peta $\bar{X}$ perbaikan parameter smoothness PS bulan Januari 2018, (b) Peta $R$ perbaikan parameter Smoothness PS bulan Januari 2018 
Ternyata setelah dilakukan perbaikan peta kendali $\bar{X}-R$ tetap terdapat titik-titik observasi yang out of control. Hal ini menjadi bahan evaluasi untuk perusahaan bahwa pada Bulan Januari 2018, masih terdapat banyak produk yang parameter smoothness untuk PS belum terkendali mutunya secara statistik. Parameter mutu smoothness pada PS ini masih sangat perlu perhatian dari perusahaan, karena dalam bulan berturut-turut parameter tersebut menunjukkan bahwa kualitasnya belum terkendali secara statistik walaupun sudah mengalami perbaikan atau revisi peta kendali. Hal ini yang dijadikan dasar untuk evaluasi lebih lanjut. Proses produksi yang menjadi salah satu penentu parameter smoothness adalah proses coating. Proses ini terdapat 3 tahap, yaitu terdiri dari 3 bagian, yaitu Coater 1 untuk aplikasi precoat (pada permukaan bottom ply), Coater 2 untuk aplikasi topcoat (pada permukaan top ply), dan Coater 3 untuk aplikasi backcoat (pada permukaan bottom ply). Kertas yang dilapisi (coated) adalah kertas yang telah dilapisi oleh senyawa atau polimer tertentu sehingga kertas dapat memiliki kualitas tertentu dari senyawa/polimer tersebut. Kualitas tersebut dapat terlihat pada bobot kertas (gramatur), permukaan kertas yang mengkilap, halus, atau tidak mudah menyerap tinta (smoothness) (Anonim, 2019).

\section{Diagram Sebab Akibat}

Diagram sebab akibat digunakan untuk mengetahui apa saja penyebab adanya penyimpangan yang terjadi pada kertas karton. Jenis penyimpangan yang dinilai didalam diagram ini adalah pada parameter Smoothness PS tinggi, warna PS kebiruan, dan warna PS mangkak. Ketiga penyimpangan ini akan dilakukan penilaian Diagram Sebab-Akibat karena pada Diagram Pareto ketiga penyimpangan ini jumlahnya lebih tinggi daripada penyimpangan yang lain. Alasan selanjutnya ada karena sebesar $80 \%$ dari seluruh jumlah kecacatan, berisi ketiga penyimpangan produk kertas karton.
Berdasarkan hasil analisa, didapat 4 macam penyebab adanya penyimpangan atau kecacatan pada produk kertas karton. Pertama adalah pada karyawan (personnel), kedua pada mesin atau alat (machines), ketiga yaitu pada bahan (material), dan keempat adalah pada lingkungan (environment). Pada penyebab pertama yaitu karyawan, sebab yang dapat terjadi yaitu karena karyawan yang bertugas sedang mengantuk, atau karena karyawan kurang waspada terhadap lingkungan di sekitarnya terkait Coating Section. Hal ini mengakibatkan kesalahan pada proses coating kertas sehingga parameter smoothness dan warna pada PS tidak sesuai dengan standar mutu.

Lalu pada penyebab kedua yaitu mesin atau alat, sebab yang dapat terjadi penyebab produk kertas karton diluar spesifikasi nilai smoothness maupun warnanya yaitu karena adanya komponen didalam proses yang kotor, atau karena tingkat perawatan dari mesin atau alat Coating Section yang terlalu sulit dijangkau oleh teknisi, atau adanya pengaturan standar operasi pada Coating Section yang tidak sesuai dengan spesifikasi produk, atau bisa karena adanya kertas yang terbakar pada Infrared pada kejadian kertas mengalami putus. Abu yang terbentuk ketika kertas terbakar dapat mengenai bagian pengaplikasian zat Coating ke permukaan kertas, yang dapat menyebabkan berubahnya nilai Smoothness PS maupun warna dari permukaan kertas. Selanjutnya pada penyebab material. Adanya penyebab berbedanya nilai Smoothness maupun nilai warna dari masing-masing permukaan kertas dapat disebabkan oleh campuran bahan dan komposisi yang digunakan pada 3 tahap Coating tidak sesuai dengan standar operasi proses produksi. Penyebab keempat yaitu lingkungan. Terdapatnya debu yang masuk ke bagian Coater Section tentu dapat mempengaruhi nilai smoothness maupun nilai warna pada permukaan kertas. Gambar dari diagram sebab akibat (fishbone) dapat dilihat pada Gambar 6.

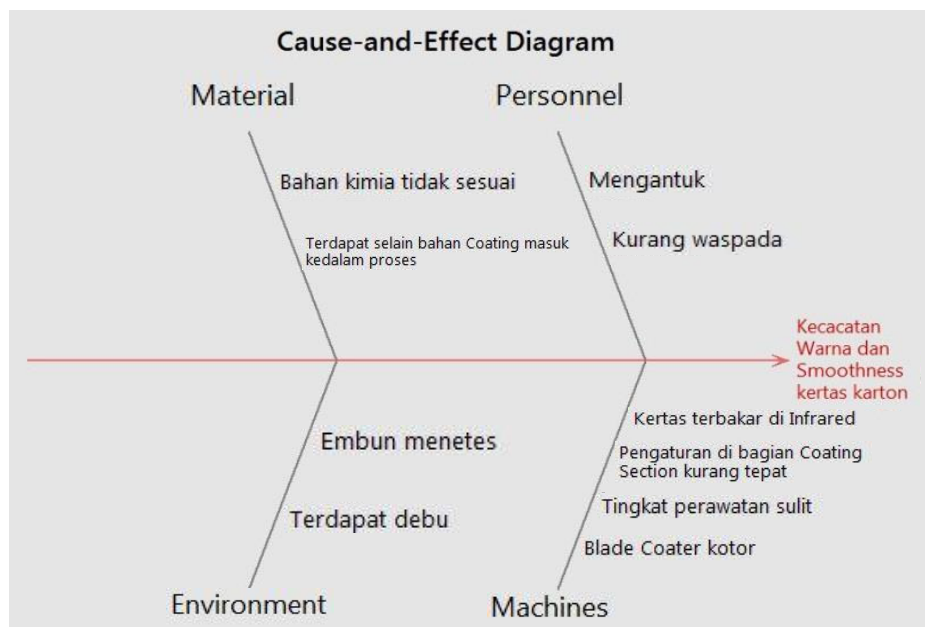

Gambar 6. Diagram sebab akibat (fishbone) kecacatan nilai smoothness dan warna kebiruan / mangkak 
Diagram sebab akibat dari parameter Smoothness dan warna dari hasil pengujian produk akhir kertas karton ini dibuat dalam satu diagram, karena dari parameter smoothness dan warnadipengaruhi oleh satu mesin yang sama (Coater Section) dan bahan Coating yang diaplikasikan juga sama.

Beberapa penelitian mengenai pengendalian kualitas akhir produk banyak dilakukan dan efketif mendeteksi penyebab permasalahan kecacatan produk. Penelitian yang dilakukan oleh Bachtiar et al. (2013) dengan tujuan untuk mengendalikan kualitas produk sirup pala dan mengidentifikasi kerusakan produk. Hasilnya dari ke 7 alat pengendalian kualitas yang telah dianalisa dapat diketahui bahwa penyebab penyimpangan kualitas pada UD. Mestika yaitu dari sekian kerusakan yang terjadi, yang paling berpengaruh adalah kerusakan pada botol jenis pecah dan retak disebabkan oleh 4 faktor yaitu manusia, material, metode dan proses

Terdapat beberapa saran perbaikan untuk dapat mengurangi jumlah kecacatan dalam produk kertas karton serta dapat mengurangi tingkat kecelakaan kerja. Saran ini dibuat berdasarkan 4 poin dasar, yaitu Personnel, Machines, Material, dan Environment.

\section{Personnel}

Pada poin personnel, saran yang dapat diberikan untuk perusahaan adalah diawali dengan memberikan himbauan untuk tenaga kerja (terutama pada Coater Section) dengan cara memberikan informasi penting tentang bahaya apa saja apabila terdapat karyawan yang mengantuk, ataupun tenaga kerja yang kurang waspada terhadap tugasnya. Pengaruh yang dapat terjadi didalam poin personnel dapat berakibat fatal, karena sebagian besar tenaga kerja terutama di bagian produksi memiliki kendali penuh terhadap mesin-mesin yang sedang beroperasi. Misalnya, didalam pengawasan tangki bahan coating yang kurang waspada, dapat menyebabkan bahan coating yang diaplikasikan nantinya tidak sesuai dengan standar warna kertas.

\section{Machines}

Didalam poin machines, saran yang dapat diberikan yaitu adalah saran preventif. Misalnya dengan melakukan pengecekan lebih rutin lagi dan lebih teliti terhadap seluruh bagian mesin atau instrumentasi didalam bagian coater section. Hal ini karena sebagian penyimpangan produk yang murni disebabkan oleh mesin dapat muncul disebabkan adanya beberapa faktor pengecekan yang terlewatkan. Misalnya, apabila pemeriksaan alat didalam proses coater section kurang baik, maka jumlah dari bahan coating yang diterapkan ke bagian permukaan kertas terdapat perbedaan dari yang seharusnya.

\section{Material}

Pada poin material, saran yang dapat diberikan adalah misalnya dengan pengecekan terhadap bahan baku kimia yang digunakan didalam seksi chemical preparation, ataupun pengecekan alur bahan coating dari coating ke alat coater section. Pengecekan ini juga berguna untuk memastikan bahan yang nantinya akan diaplikasikan di coater section tidak ada bahan asing yang terikut dalam bahan coating. Berbagai campuran bahan kimia yang diaplikasikan dapat berpengaruh terhadap produk akhir yang dihasilkan nantinya. Oleh karena itu, tindakan pengecekan yang lebih rutin dan lebih ketat terhadap bahan kimia yang digunakan untuk aplikasi coating sangat diperlukan

\section{Environment}

Poin terakhir yaitu environment, terdapat saran yang dapat diberikan kepada perusahaan. Salah satunya adalah dengan memperbaiki akses keluar masuk yang ada didalam perusahaan. Misalnya dengan cara memperbaiki kisi-kisi karet di bagian pintu keluar masuk dari tenaga kerja dan kendaraan pengangkut, ataupun dengan membersihkan ventilasi udara dan mengatur sirkulasi yang ada didalam lingkungan perusahaan. Hal ini untuk mengatasi penyebab banyaknya kotoran dan debu yang masuk ke dalam ruang produksi. Selanjutnya untuk penyebab embun yang menetes, hal ini dapat mempengaruhi bagian permukaan kertas menjadi tidak sama (apabila menetes pada bagian alat Coater), mempengaruhi konsentrasi coating yang akan diaplikasikan (apabila menetes di tangki coating), atau bisa juga menjadikan lembab dari kondisi kertas jadi. Adanya akibat-akibat tersebut dapat disarankan adanya penyesuaikan kondisi yang ada didalam perusahaan dengan kondisi di lingkungan. Embun terjadi karena suhu didalam perusahaan yang lebih panas daripada suhu yang ada di lingkungan (misal, hujan), maka dapat disarankan adanya pendingin di sekitar mesin produksi.

\section{KESIMPULAN DAN SARAN}

\section{Kesimpulan}

Pada diagram pareto untuk data kecacatan kertas bulan Desember 2017 dan Januari 2018 dapat dilihat jumlah kecacatan tingkat smoothness yaitu 10, warna PS sejumlah 8, warna PS mangkak sejumlah 7, nilai thickness sejumlah 3, cacat coating sejumlah 1, dan sebab lain sejumlah1. Dari pengujian bagan kendali proses, data yang diukur yaitu smoothness PS, dengan waktu Bulan Desember 2017 dan Januari 2018. Data smoothness PS baik pada bulan Desember 2017 maupun Januari 2018 terdapat data yang belum terkendali kualitasnya secara statistik. Terdapat poin observasi yang keluar dari batas dapat disebabkan karena adanya jumlah bahan coating yang diberikan kepada kertas tidak sesuai dengan ketentuan (terlalu banyak atau terlalu 
sedikit), atau bisa juga dikarenakan adanya pengaturan didalam mesin yang digunakan dalam proses produksi yang tidak sesuai (terutama di Coater Section). Selanjutnya pada diagram sebab akibat, dibuat dengan berdasarkan Diagram Pareto. Hasil analisis penyebab kecacatan pada kertas karton yaitu personnel, machines, material, dan environment.

\section{Saran} pemeriksaan kualitas kertas karton secara multivariate, yaitu dengan memasukkan beberapa variabel mutu kertas secara bersamaan menggu nakan peta kendali multivariat, perlu dilakukan penelitian yang lebih mendalam mengenai level sigma serta kapabilitas proses produksi di perusahaan terkait.

\section{DAFTAR PUSTAKA}

Anonim. 2019. Pelapisan kertas PT. Lautan Luas Tbk. $\quad$ http://www.lautan-luas.com/id/i ndustries/products/pulp paper/process/paper-coating/ [10 Februari 2018]

Arifianti R. 2013. Analisis kualitas produk sepatu tomkins. Jurnal Dinamika Manajemen. 4 (1): 46-58.

Arsyad AG, Ferdinant PF, dan Ekawati R. 2017. Analisis peta kendali $\mathrm{p}$ yang distandarisasi dalam proses produksi regulator set fujiyama. Jurnal Teknik Industri. 5 (1): 86 92.
Badiru AB, Ibidapo-Obe O, dan Ayeni BJ. 2012. Industrial Control Systems: Mathematical and Statistical Models and Techniques. Boca Raton: CRC Press.

Bakhtiar S, Tahir S, dan Hasni RA. 2013. Analisa pengendalian kualitas dengan menggunakan metode Statistical Quality Control (SQC). Malikussaleh Industrial Engineering Journal. 2 (1): 29-36.

Devani V dan Wahyuni F. 2016. Pengendalian kualitas kertas dengan menggunakan Statistical Process Control di Paper Machine 3. Jurnal Ilmu Teknik Industri. 15(2):87-93.

Heizer J dan Render B. 2005. Manajemen Operasi. Edisi 7. Jakarta: Salemba Empat.

Kartika H. 2013. Analisis pengendalian kualitas produk cpe film dengan metode Statistical Process Control pada PT. MSI. Jurnal Ilmiah Teknik Industri. 1: 50-58.

Kementrian Perindustrian Republik Indonesia.2018. Industri pulp dan kertas dipacu manfaatkan teknologi ramah lingkungan.retrieved from http://www.kemenperin.go.id/artikel/19895/ Industri-Pulp-dan-Kertas. [15 Maret 2018]

Nur R dan Suyuti M. 2017. Pengantar Sistem Manufaktur. Yogyakarta: Deepublish.

Primastuti NB. 2014. Pengontrolan kualitas produk menggunakan metode diagram kontrol multivariat np (Mnp) dalam usaha peningkatan kualitas (Studi Kasus di PT Coca-Cola Amatil Indonesia (CCAI) Semarang). Jurnal Gaussian. 3 (1): 11-119. 